DOI 10.18551/rjoas.2020-01.19

\title{
FACTORS THAT AFFECT EQUITY FINANCING IN SHARIAH MANDIRI TBK BANK
}

\author{
Apriyanti Tuti, Effendi Jaenal, Burhanuddin \\ School of Business, Bogor Agriculture University, Indonesia \\ ${ }^{\star}$ E-mail: tutipb87@gmail.com
}

\begin{abstract}
Equity financing has an important role in driving financing in the real sector. The core business of Islamic banking is based on the real sector but the portion of financing in Islamic banking is currently still dominated by debt financing. This study aims to analyze the factors that influence equity financing at Bank Syariah Mandiri. This study uses the Error Correction Model (ECM) method. The results showed that the most influential factor on equity financing was the BI Rate. Then followed by internal variables DPK, CAR, ROA, NPF, BOPO, FDR, and the external factor is inflation.
\end{abstract}

\section{KEY WORDS}

Islamic banking, equity financing, mudaraba, musharaka, error correction model.

A bank is a business entity that collects funds from the public in the form of deposits and distributes them to the public in the form of financing. The Bank has three main functions, namely receiving deposits from the public, channeling funds in the form of credit, and providing various services in domestic and international trade and payment activities. In Islamic banking lending in the form of financing, the higher the financing disbursed, the greater the contribution of banks in accelerating the distribution of public income.

Funding channeled by banks is influenced by internal and external factors. Internal factors include the bank's financial capacity and financing policies, while external factors include economic stability and government policy support. Berrospide et al. (2010), Haryati (2009), Zulverdi et al. (2007), Baum et al. (2008), Ascarya (2012), Priyanto (2015).

Table 1 - Growth in Sharia Bank Financing

\begin{tabular}{ccc}
\hline Year & Financing (Billion) & Growth (\%) \\
\hline 2007 & 28.837 & - \\
2008 & 38.199 & 32,47 \\
2009 & 46.885 & 22,74 \\
2010 & 68.181 & 45,42 \\
2011 & 102.655 & 50,56 \\
2012 & 147.505 & 43,69 \\
2013 & 184.122 & 24,82 \\
2014 & 199.330 & 8,259 \\
2015 & 212.996 & 6,866 \\
2016 & 248.007 & 16,44 \\
2017 & 285.695 & 15,20 \\
2018 & 281.743 & 1,38 \\
\hline
\end{tabular}

Source: Statistik Perbankan Syariah, diolah (2019).

In the last ten years, the growth of financing in Islamic banks has been very volatile. The cause of these conditions is that in 2008-2012 there was an economic crisis that caused interest rates to fluctuate. This has an impact on the growth of financing. In 2014-2015 financing in Islamic banks was only $8,259 \%$ and $6.688 \%$. The slowdown in economic growth is due to the rising political temperature in Indonesia which is holding a presidential election. The slowing down is back in 2018. This year is the smallest year of growth in Islamic bank financing. the cause is none other than the rise in political tribes in the 2019 presidential election. 
Financing at Islamic banks is divided into two, namely debt based financing and debt financing based. Debt financing is usually used for financing in the context of meeting consumer needs. Debt financing usually uses murabahah, salam, and istishna contracts. Equity financing is usually used to finance the fulfillment of working capital and investment. Equity financing usually uses mudharabah and musyarakah contracts.

The essence of the presence of Islamic banks is to create business practices that are just and in direct contact with the real sector to grow the business sector and income distribution. Financing that supports this goal is equity financing or in accordance with the core business of Islamic banks. (Ascarya, 2012). But on the way Islamic banks are still concentrated in debt financing, or about 60 percent of the financing portfolio. In several studies that have been conducted, the cause of the low equity financing is the existence of asymetric information that has the potential to cause losses and disrupt the bank's capital adequacy ratio.

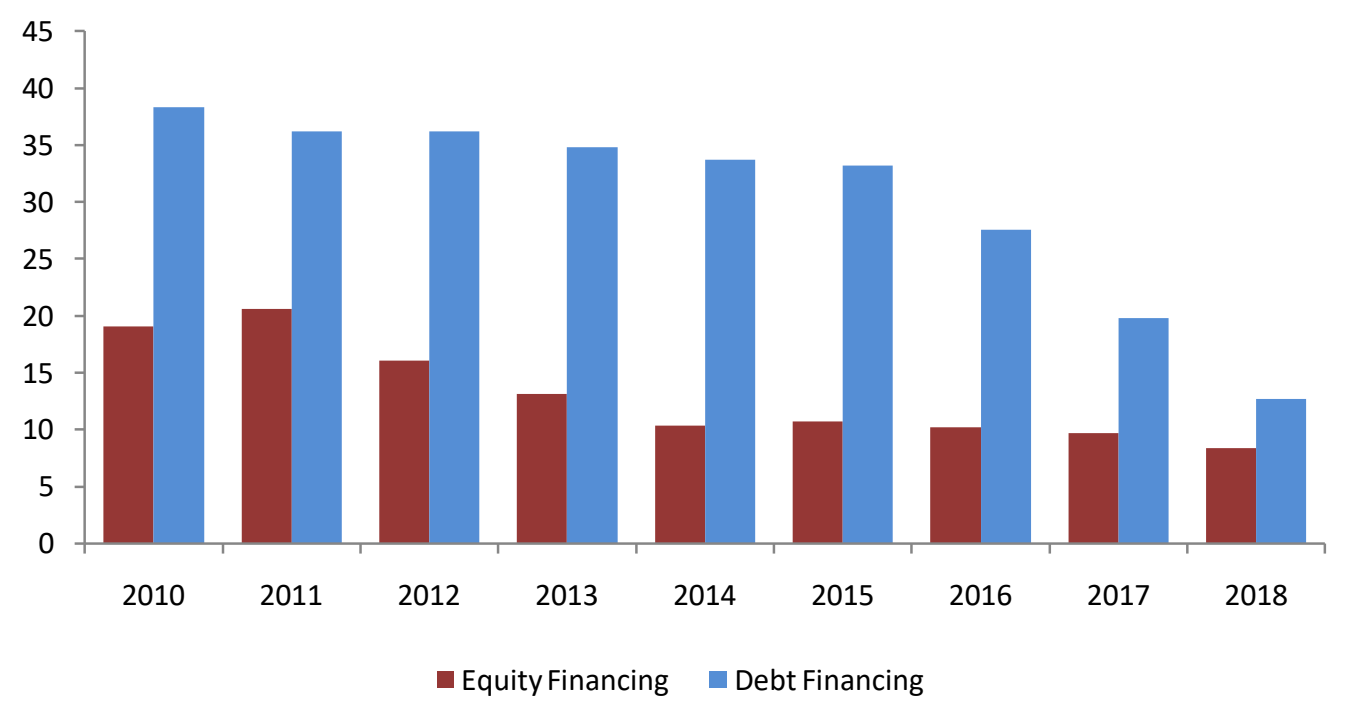

Figure 1 - BSM Financing Growth Trends (Mlns). Source: Annual Report BSM.

Bank Syariah Mandiri (BSM) as the largest Islamic bank in Indonesia has financing that is still concentrated in debt financing based financing. Over the past eight years, the portion of debt financing has always been higher compared to equity financing. In 2017 debt financing at Bank Syariah Mandiri (BSM) reached 52 billion rupiah or $73 \%$ of total financing. While the amount of equity financing is only 19.71 billion rupiah or 19.71 percent of the total financing. Such conditions do not reflect the core business of Islamic banking itself. According to Yulianto and Asrori (2012), equity financing is a financing product that shows core business in Islamic banks.

This thesis is focused on the factors that influence equity finacing in BSM. This bank is quite representative of Islamic banking, which has been listed at three Sharia General Banks (BUS) in Indonesia since 2000. However, the financing portfolio is still concentrated in debt financing. So it can be said that BSM is still not focused on developing profit-sharing based financing which is the core business of Islamic banking itself.

\section{LITERATURE REVIEW}

Equity financing is influenced by internal factors and external factors, namely internal and external variable.

Dana Pihak Ketiga (DPK) is funds entrusted by the public (outside the bank) to banks based on fund storage agreements. In banking operations, DPK is a source of liquidity to facilitate financing contained in the assets of the bank's balance sheet. According to Law No. 21 of 2008 concerning Sharia Banking (Article 1) states that deposits are funds entrusted by 
customers to Islamic banks and / or UUS based on wadiah agreements or other contracts that do not conflict with sharia principles in the form of demand deposits, savings, or other forms equivalent to that. According to Muhammad (2005) one source of funds that can be used for financing is deposits (DPK). So that the greater the deposited deposits, the greater the amount of funding channeled, including equity financing.

According to Rachman and Apandi (2015) CAR is a ratio used to measure the adequacy of capital owned by banks to support assets that have risks, for example financing provided. Based on Bank Indonesia Regulation Number 3/21 / PBI / 2001, banks are required to provide a minimum capital of 8 percent of the Risk Weighted Assets (RWA) stated in the CAR. The way to find out whether a bank meets the CAR requirements (capital adequacy) or not is to compare the results of the calculation of capital ratios and minimum capital supply obligations equal to 100 percent or more.

Return on Assets (ROA) is used to measure the ability of bank management in obtaining profits (profit before tax) generated by the average total assets of the bank concerned. The greater the ROA, the greater the level of profits achieved by banks so that the possibility of banks in problematic conditions is smaller. Profit before tax is the net profit from operational activities before tax. Meanwhile, the average total asset is the average volume of business or assets.

Financing Deposit Ratio (FDR) is a ratio that illustrates the level of ability of Islamic banks to return third party funds through profits derived from financing (Rachman and Apandi 2015). Based on Bank Indonesia Circular No. 26/5 / BPPP the amount of FDR determined by Bank Indonesia may not exceed 110 percent, which means that banks may provide funding in excess of the amount of third party funds collected provided that it does not exceed 110 percent.

Non Performing Finance (NPF) is credit that does not have a good performance and is classified as substandard, doubtful, and bad; the smaller the NPF percentage, the better the quality of financing at the bank.

BOPO (Belaja Operasional terhadap pendapatan Operasional) is a ratio that illustrates the efficiency of banks in carrying out their activities. Operational expenditure is interest expense given to customers while operating income is interest earned from customers. The smaller the value of BOPO means more efficient banking in operating.

Inflation is a general and continuous increase in prices (Bank Indonesia 2017). Rising prices of goods caused by inflation make the value of money and purchasing power of the people decrease, so the demand for goods and services also decreases. In general, these conditions make the business sector reduce the amount of production. The reduced production has caused entrepreneurs to reduce their investment, which in turn has led to decreased demand for financing to the banking sector. In other words, a high inflation rate will reduce the financial sector and the real sector, which in turn causes economic growth to be low.

BI Rate is a policy interest rate that reflects the monetary policy stance set by Bank Indonesia and announced to the public (Bank Indonesia 2017). Although Islamic banks do not use the interest system, the reality is that Islamic banks still refer to the $\mathrm{BI}$ rate set for conventional banks when providing financing. This is because the majority of Indonesian people prefer loans with returns that are not too high without seeing an institution using interest or not.

\section{METHODS OF RESEARCH}

The data used uses secondary data, including the monthly reports of PT Bank Bank Syariah Mandiri Tbk, the monthly financial statements of PT Bank Bank Syariah Mandiri Tbk, the monthly data of Bank Indonesia Reference Interest Rate (BI-7 Days RR Rate) and Inflation data. All of this data uses a time span from 2000-2018. Other types of literature used are in the form of books, journals, internet and literature studies related to this research. 
Table 2 - Research variable

\begin{tabular}{llll}
\hline No & Data Type & Variable & Source \\
\hline 1 & Internal Factor & DPK & PT Bank \\
& & CAR & Syariah Mandiri Tbk \\
& & ROA & \\
& & NPF & \\
2 & BOPO & BI \\
& External Factor & Inflation & BI \\
\hline
\end{tabular}

The ECM model used in this study to investigate the factors that influence the amount of equity financing in the short term is as follows:

$$
\begin{aligned}
\mathrm{DJF}_{t}=b_{0}+b_{1} \mathrm{D}(\mathrm{DPK} t)+b_{2} \mathrm{D}(\mathrm{CAR} t) & +b_{3} \mathrm{D}(\mathrm{ROA} t)+b_{4} \mathrm{D}(\mathrm{FDR} t)+b_{5} \mathrm{D}(\mathrm{NPF} t)+b_{6} \mathrm{D}(\mathrm{BOPO} t)+b_{7} \mathrm{D}(\mathrm{IN} t) \\
& +b_{8} \mathrm{D}(\mathrm{BIRate} t)+\mathrm{B}_{10} \mathrm{EC}_{\mathrm{T}-1}+u_{t}
\end{aligned}
$$

Where: $\mathrm{D}=$ Difference; ECT $t-1=e t-1=(Y t-1-Y t-1)=\operatorname{Lag} 1$ period of residual value that can be interpreted as an error correction component from the previous time period $(\mathrm{t}-1)$; $u t=$ Disturbance error in period $t$.

\section{RESULTS AND DISCUSSION}

Data stationarity test to find out whether the time series data that will be used for analysis needs to be stationary or not. Non-stationary data must be avoided because it will cause false regression. The first test will be carried out at the level using MacKinnon critical value at $5 \%$.

Stationary Test Results for DPK, CAR, ROA, NP, BOPO, Inflation, and BI rate are not stationary at the level because the absolute value of the 5th ADF variable is smaller than the absolute value of MacKinnon. Because there are still non-stationary data, the unit root test will be performed on First Difference.

The results of the stationarity test data on the first difference show that the eight variables used in the study were stationary at the first difference level. This is because the absolute value of ADF is greater than the absolute value of MacKinnon Critical Values.

Cointegration test is used to give an early indication that the model used has a longterm relationship (cointegration relation). Cointegration results are obtained by forming a residual obtained by regressing the independent variable on the dependent variable. The residual must be stationary at the level of level to be said to have cointegration.

Table 3 - Cointegration Test on residuals $(\mathrm{u})$

\begin{tabular}{c|c|c|c|c}
\hline Model & Variable & t count & Prob & Information \\
\hline Total Pembiayaan & U1 & -3.059444 & 0.0343 & Cointegrated \\
\hline
\end{tabular}

Note: * stationary at Mac Kinnon Critical value $(\alpha=5 \%)$.

CAR variable has a positive and significant effect on the amount of equity financing in the long run with a coefficient value of 0.0011 which is smaller than $(\alpha=5 \%)$. CAR value of 0.0011 percent means an increase in CAR of 0.0011 percent will increase equity financing will increase by 0.011 . the results of this study are in line with research conducted by Katmas (2014) which states that CAR has a positive and significant effect on equity financing due to the small amount of reserves provided for RWA so that the portion of financing increases. This study also contradicts Mulianingtiyas (2015) which states that CAR negatively affects the volume of profit sharing financing.

Processing ROA variables have a positive effect on the real level $(\alpha=5 \%)$ of total financing with a value of 0.1358 . This means that if ROA has the potential to increase by $1 \%$, the total financing will increase by 0.1358 .

The ability of Islamic banks to print profitability is still lower than conventional banks. This is because Islamic banks bear the cost of funds or a higher cost of funds accompanied 
by an increase in operational costs. This is proven by the ROA ratio at BSM of only $0.88 \%$. Whereas in theory the higher the value of ROA shows the better company performance.

The NPF variable processing has a positive effect on the real level $(\alpha=5 \%)$ of the total financing with a value of 0.0762 . This means that if the NPF increases by $1 \%$, the total financing will increase by 0.0762 . The results of this study are not in line with research conducted by Nugraha (2014) and Muliawati (2015). NPF is one of the variables that shows the performance of Islamic banking and is a ratio of problem financing to the amount of financing provided. The increase in the number of deposits raised by Islamic banking was not followed by a portion of equity financing. Because equity financing is small, NPF on equity financing is considered not to have a large influence on financing so that Islamic banks focus on channeling financing in line with the increasing number of DPK.

BOPO variable processing has a negative effect on the real level ( $\alpha=5 \%$ ) on total financing with a value of 0.0109 . This means that if the BOPO increases by $1 \%$, the total financing will decrease by 0.0109 .

BSM is more efficient, reflected in the decline in the BOPO ratio from $94.44 \%$ in 2017 to $90.68 \%$ in 2018 . The decline in the BOPO ratio is around $3.76 \%$. In running its business, BSM is constrained by improving the efficiency of bank operations. Therefore, BSM sets focus on strategies related to productivity and efficiency. Related to this, BSM implemented a work program to increase the application of contribution margin in the context of the effectiveness of performance appraisal. The implication of this strategy is a decrease in the ratio of operating costs to operating income (BOPO) from $94.44 \%$ in 2017 to $90.68 \%$ or decreased by $3.76 \%$.

Processing of FDR variables has a positive effect on the real level ( $\alpha=5 \%$ ) of total financing with a value of 0.0955 . This means that if FDR increases by $1 \%$, the total financing will increase by 0.0955 . This result is in accordance with the initial hypothesis. An increase in the $\mathrm{BI}$ rate causes an increase in conventional bank interest rates, which in turn leads to bad loans or the ability of customers to repay loans. As a result, customers will switch to choosing Islamic financing that has a lower rate of return than conventional bank interest. As a result, an increase in the $\mathrm{BI}$ rate resulted in the amount of equity financing. These results are in line with research conducted by Katmas (2014) which states that the BI rate has a positive and significant effect on Islamic banking financing, due to the high level of conventional bank interest rates causing people to switch to using Islamic financing with lower returns.

Policy Implications. Some of the policy implications made to increase equity financing in BSM include:

- Financing plans based on product segments can be linked to the contract used. Missal: commercial financing with mudharabah contracts and retail segment with musyarakah. The hope is to increase the position of mudharabah and musyarakah financing;

- Continuing and improving the plan for raising funds which has been done so far, namely by increasing CASA to get low cost funds and optimizing deposit collection from customers;

- In preparing the funding plan and collecting deposits, it is always aligned with macro assumptions such as changes in inflation, the $\mathrm{BI}$ Rate, the exchange rate, and other macroeconomic indicators;

- To reduce asymmetric information in the presentation and submission of business results reports, it is necessary to strengthen the analysis of customer character in the initiation of financing and analysis of business management capabilities as well as the preparation of financial statements and results of operations;

- Providing business management assistance and preparation of financial reports, especially for MSME customers who do not yet have the ability. This is important to do to simplify the monitoring process;

- Collaborating with institutions that carry out special missions in developing certain real sectors both on the side of raising funds and on the distribution of financing; 
- Provide training on the characteristics of the types of businesses or businesses that are targeted for financing. For example: providing training on the characteristics of agriculture or plantation business, telecommunications business, energy business, services, and various other types of businesses. So that the risk of loss can be minimized;

- Conduct training for employees related to financing in all segments;

- Recruiting new employees who have Islamic banking education background;

- 10. Providing socialization to the public to introduce BSM products as well as providing understanding related to the concept of BSM as the largest Islamic bank that is free from usury;

- Provide information and input to the financial authorities (BI and OJK) to give priority in issuing instruments other than the BI Rate that can be used as a reference for Islamic banks in determining the size of the profit sharing ratio and various profitsharing based financing policies in Indonesia.

\section{CONCLUSION}

Factors affecting equity financing in BSM are influenced by internal and external factors. $\mathrm{BI}$ rate is considered as the variable that most influences equity financing in BSM. BI rate is one of the government instruments in controlling the economy. Today, BSM still uses the $\mathrm{BI}$ rate in determining the profit sharing ratio for deposits and financing.

Some of the policies that can be carried out by BSM management to increase mudharabah and musyarakah financing, namely: financing plans based on product segments can be linked to the contract that is used, Continuing and increasing the fund collection plan that has been done so far, namely by increasing CASA to obtain funding costs cheap and optimize deposit collection from customers in preparing financing plans and collecting deposits, always aligned with macro assumptions such as changes in inflation, the BI Rate, exchange rates, and other macroeconomic indicators, to reduce asymmetric information in the presentation and delivery of business results, it is necessary to strengthen analysis character of customers in the initiation of financing and analysis of business management capabilities and preparation of financial statements and results of operations. provide assistance in business management and preparation of financial reports, especially for MSME customers who do not yet have the ability. This is important to be done to facilitate the monitoring process in collaboration with institutions that carry out a special mission in developing certain real sectors both in the collection of funds and in the distribution of funding, providing training on the characteristics of the types of businesses or businesses that are targeted for financing. For example: providing training on the characteristics of agriculture or plantation business, telecommunications business, energy business, services, and various other types of businesses. So that concerns about the risk of loss can be minimized, training employees related to financing in all segments, recruiting new employees who have a background in Islamic banking education, giving socialization to the public to introduce BSM products and providing understanding related to the concept of BSM as the largest Islamic bank, free from usury, provide information and input to the financial authorities ( $\mathrm{BI}$ and $\mathrm{OJK}$ ) in order to give priority in issuing instruments other than the $\mathrm{BI}$ rate that can be used as a reference for Islamic banks in determining the size of the profit sharing ratio and various profit-sharing based financing policies in Indonesia.

Based on the statements that have been presented in the study, internal factors that have been processed by the Error Correction Model (ECM) have an effect on equity financing. Suggestions for future research, the focus of research is only on internal factors, especially the ability of management to develop financing strategies, funding, and improving employee quality. Improving the quality of employees by menghire employees who really understand Islamic banks. As noted, BSM leaders are still from PT Bank Mandiri (Persero) Tbk. 


\section{REFERENCES}

1. Adzimatinur, F, Hartoyo S., Wiliasih, R., 2015. Faktor yang Mempengaruhi Besaran Pembiayaan, Jurnal Al-Mubara'ah, P:2337-6333 ; e:2355-4363

2. Ascarya A. 2012. Alur Tranmisi and Efektivitas Kebijakan Moneter Ganda di Inonesia. Buleting Ekonomi Moneter and Perbankan Bank Indonesia. 14(3): 283-315.

3. Baum C, Caglayan M, Ozkan N. 2004. The Second Moments Matter: The Response of Bank Lending Behaviour to Macroeconomic Uncertainty. Working Paper. 04(13)

4. Baum C, Caglayan M, Ozkan N. 2008. The Second Momments Matter: The Impact Macroeconomic Uncertainty on the Allocation of Loanable Funds. Economic Letter 102: $42-44$

5. Berrospide, Jose ME, Rochelle M. 2010. The Effect of Bank Capital on Lending: What do we know and what does it mean?. International Journal of Central Banking 6(4): 5 - 50

6. [BI] Bank Indonesia. 2018. Data Tingkat Inflasi. Http://www.bi.go.id [17 Januari 2018]

7. $[\mathrm{BI}]$ Bank Indonesia. 2018. Laporan Perkembangan Perbankan Syariah (LPPS). Http:/www.bi.go.id [30 Maret 2018]

8. [BI] Bank Indonesia. 2018. laporan Profil Industri Perbankan. Http://www.bi.go.id [17 Januari 2018]

9. [BI] Bank Indonesia. Berbagai Tahun. Statistik Perbankan Syariah. Direktorat Perizionan and Informasi Perbankan BI. http:www.bi.go.id [15 Januari 2017]

10. Haryati S. 2009. Pertumbuhan Kredit Perbankan di Indonesia: Intermediasi and Pengaruh Variabel makroekonomi. Jurnal Keuangan and Perbankan 12(2): 299 - 310.

11. Katmas, Ekarina. 2014. Pengaruh Faktor Eksternal and Internal terhadap Volum Pembiayaan Perbankan Syariah di Indonesia: Jakarta

12. Muliawati, Sri. 2015. Faktor-Faktor Penentu Profitabilitas Bank Syariah di Indonesia. Jurnal Unnes, 10. 15294/MAJ.V11.7211

13. Priyanto, et al. 2016. Faktor-Faktor yang Mempengaruhi Pembiayaan Berbasis Bagi Hasil (Equity Financing) pada Bank Syariah X. Jurnal Aplikasi Bisnis and Manajemen 2(3)

14. Reswanda, Wahyu. 2014. Pengaruh DPK, CAR, FDR, and NPF terhadap Penyaluran Pembiayaan pada BPRS Lantabur Jombang, Jurnal Universitas Jember, p: 1084 vol 13 No.2

15. Undang - Undang Republik Indonesia No.21 Tahun 2008 tentang Perbankan Syariah. Http://www.hukumonline.com [17 Januari 2018]

16. Zulverdi D, Gunadi I, Pramono B. 2007. Bank Portfolio Model and Monetary Policy in Indonesia. Journal of Asian Economics 18(1): 158 - 174. 